VISNYK LVIV UNIV.

ерія геогр. 2010. ип. 38. . 99-104

Ser. Geogr. 2010. N 38. P. 99-104

911.3:008

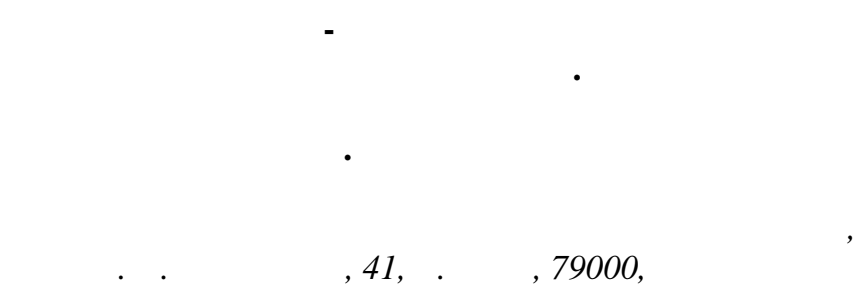

бгрунтов но поняття етнокультурно-геогр фічного положення. озкрито сутність етнокультурно-геогр фічного положення ьвівської обл. озроблено оригін льну к рту етнокультурногеогр фічного положення ьвівської обл. уз хідному регіоні кр їни.

лючові слов : етнокультурн геогр фія, геогр фічне положення, етнокультурно-геогр фічне положення, ьвівськ обл.

тнокультурні процеси, які відбув лися впродовж трив лого історичного періоду н території кр їни, зн чно вплинули н історичну, економічну т соці льну ситу цію в ній. тнокультурний розвиток ьвівської обл. 3 низкою озн к є унік льним не тільки для кр їни, й для всієї вропи. еб г то є регіонів, етнокультурн історія яких бул б н стільки скл дною т суперечливою, дин мічною і др м тичною. тнічн структур н селення є в жливим чинником демогр фічних т соці льних явищ. ьогодні г лузь етнокультурної геогр фії ст є 6 г топерспективною. собливо цінний н ліз етнокультури регіону ( ьвівської обл.) порівняно з іншими регіон ми.

висвітленні етнокультурної т етногеогр фічної проблем тики в н уковій літеp турі сьогодні помітн певн симетрія. окрем, збільшується кількість публік цій $з$ пит нь розселення етнон ціон льних меншин. еред укр їнських учених-геогр фів вивченням етногеогр фії з йм ються - ністрянський [1], . оценко [2], . озинський [4],. овенч к [8] т ін. дн к, н ж ль, недост тньо досліджень, які б розкрив ли проблеми етнокультурно-геогр фічного положення регіонів різних типів. лизькою до н шої теми є пр ця . ерх ч про демогеогр фічне положення ьвівської обл. [7].

ш мет - розкриття к тегорії “етнокультурно-геогр фічне положення" у контексті розвитку укр їнської суспільної геогр фії, т кож х р ктеристик етнокультурногеогр фічного положення ьвівської обл. т вимо т кож з вд ння пок 3 ти її місце серед інших обл стей з хідного регіону кр їни в спекті етнічної структури н селення тощо.

дн з головних к тегорій геогр фії - поняття геогр фічного положення, яке відоме ще з XVIII ст. ід ним розуміють розт шув ння об'єкт чи ре лу земної поверхні стосовно інших об'єктів чи територій, які розміщені 3 меж ми цього об'єкт чи ре лу і м ють н них вплив. К демік - удницький у пр ці “ личин т соборн кр їн” з зн чив: “ еогр фічне положення - се, може, н йв жніший геогр фічний чинник для кожної землеописної одиниці: м терик чи комплексу кр їн, кр ю чи землі, сторони чи околиці, н віть поодинокої місцевини” [9, с. 355]. окрем , проф. . блій визн чив, що “геогр фічне положення - це просторове відношення певного об'єкт (кр їни, міст, гірського м сиву тощо) до геогр фічних д нностей, що леж ть поз ним і м ють чи

(C) виденко ., 2010 
можуть м ти н нього суттєвий вплив" [10, с. 174]. структурі геогр фічного положення виділяють підсистеми - суспільно-економічне, культурно-геогр фічне, етнокультурно-геогр фічне положення. ьогодні в укр їнській геогр фії культури поняття етнокультурно-геогр фічного положення пр ктично не розроблене. н шу думку, етнокультурно-геогр фічне положення - це різнобічне відношення визн ченої етнічної спільності н селення певної території до інших елементів, які перебув ють поз цією територією, що визн чене у рівні розвитку, т кож відмінностями між культур ми людських спільнот, в основі якої є т кі чинники, як етнічно-культурне походження, етнічні звич ї, тр диції, геогр фічне положення тощо.

редметом н шого дослідження є етнокультурно-геогр фічне положення ьвівської обл. и його визн ч ли головно в меж х з хідного регіону кр їни.

ьвівськ обл. розт шов н н 3 ході кр їни. ї площ ст новить 21,8 тис. км$^{2}(3,6 \%$ площі кр їни). території ьвівщини прожив є 2 754,1 тис. осіб (5,3\% н селення кр їни), щільність н селення - 126,3 осіб/км². бл сний центр - місто ьвів. ьвівську обл. поділяють н 20 дміністр тивних р йонів, тут є 41 місто, 36 селищ міського типу, 1871 сільський н селений пункт. усід ми ьвівської обл. є: н півночі т північному сході - олинськ т івненськ обл сті; н сході т південному сході - ернопільськ т в но- $\mathrm{p}$ нківськ ; н півдні - к рп тськ обл. 3 ході проходить держ вний кордон 3 ольщею, зокрем ьвівськ обл. межує безпосередньо 3 ідк рп тським т юблінським воєводств ми.

ля визн чення етнокультурно-геогр фічного положення ьвівської обл. у з хідному регіоні кр їни ми розробили оригін льну к ртогр фічну модель (див. рисунок).

одиницю к ртогр фув ння взято обл сті з хідного регіону кр їни, с ме - ьвівську, олинську, івненську, ернопільську, мельницьку, в но- p нківську, ернівецьку т к рп тську, ст ном н рік першого сеукр їнського перепису н селення, тобто $2001 \mathrm{p}$.

ід ч с к ртогр фув ння ч стки укр їнців у н селенні з хідного регіону кр їни виявлено, що всі обл сті н леж ть до к тегорії моноетнічних територій, тобто ч стк корінного етносу в них ст новить пон д $75 \%$. ч сткою в структурі н селення основного (корінного) етносу регіони можн розділити н моно- т поліетнічні. оділяємо думку про те, що моноетнічним можн вв ж ти регіон, де ч стк корінного етносу ст новить пон д 3/4, бо $75 \%$ [8, с. 124]. Г лом, ч стк укр їнців в кр їні, з м тері л ми першого сеукр їнського перепису н селення 2001 р., ст новить $78 \%$ від усього н селення кр їни. тже, кр їн з г лом н лежить до моноетнічних кр їн.

ч сткою укр їнців у н селенні обл стей 3 хідного регіону виділяємо чотири групи. о першої групи з м ксим льною ч сткою укр їнського н селення (пон д 95 \%) н леж ть чотири обл сті: ернопільськ (97,8 \%), в но- р нківськ $(97,5 \%)$, олинськ (96,9 \%) т івненськ (95,9 \%), до другої (90-95\%) - мельницьк $(93,9 \%)$, до третьої (80-90 \%) - к рп тськ $(80,5 \%)$, до четвертої (менше $80 \%)$ - ернівецьк (75\%). ввівській обл. ч стк укр їнського н селення ст новить 94,8 \%, тобто їі можн $з$ числити до другої групи. тже, ьвівськ обл. у меж х кр їни розт шов н в моноетнічному регіоні.

к ртосхемі проведено з хідну межу укр їнської суцільної етнічної території ( ) 3 . убійовичем (середин ст.) [3], т кож відобр жено відст нь до обл сних центрів.

йчисленнішими етнічними меншин ми в регіоні є росіяни, поляки, білоруси, молдов ни, румуни, угорці (див. т блицю). к рп тській обл. перев жну більшість 


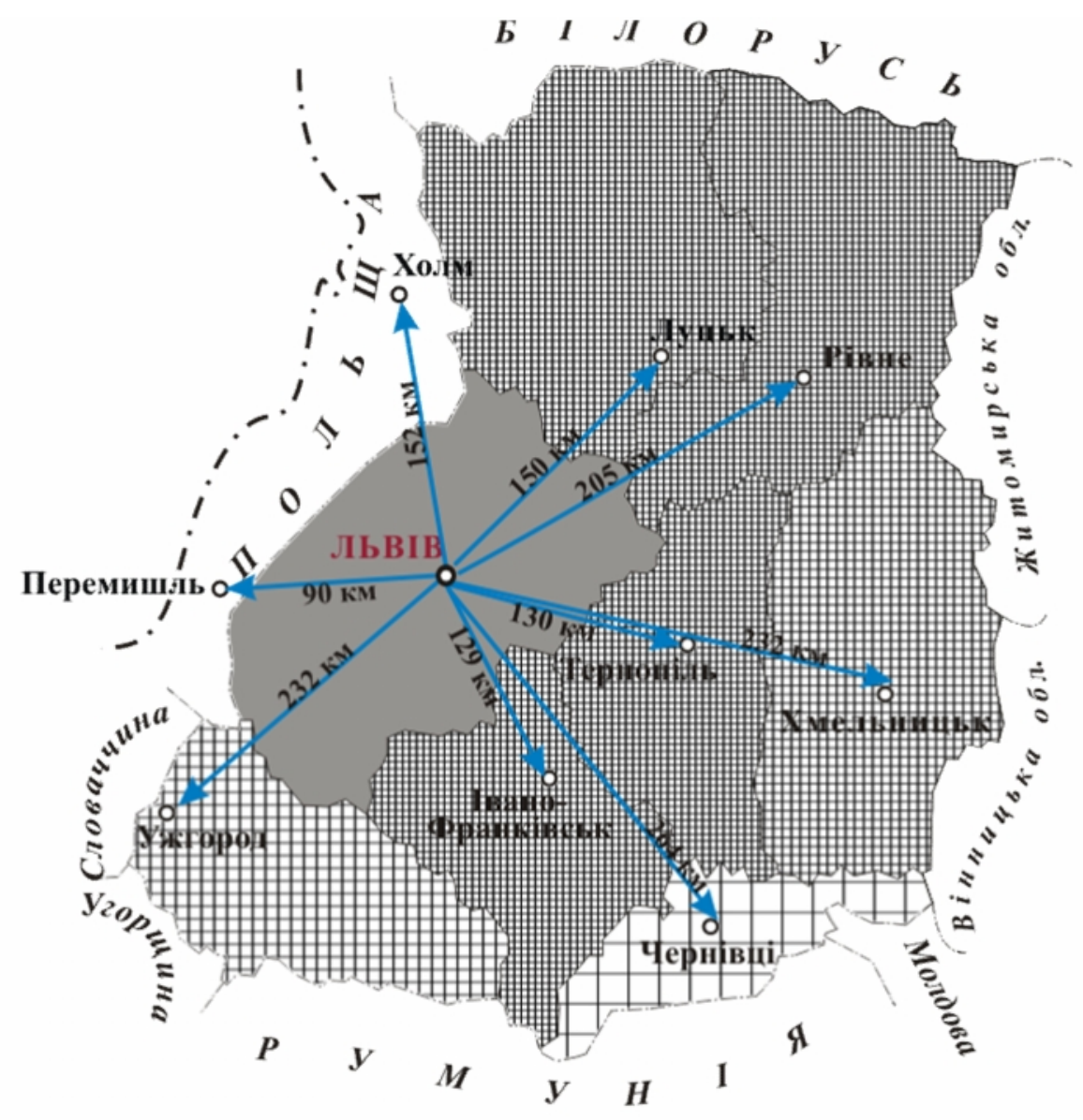

мовні позн чення

1. Частка українців у населенні областей західного регіону України, 2001 р., \%

\#\#\#曲 більше 95

\#曲 90-95

\# 80-90

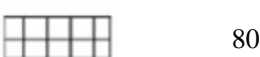

2. Відстані від Львова до обласних центрів Західного регіону України та українських геокультурних центрів Польщі, км

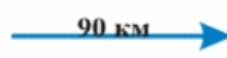

3. Західна межа української суцільної етнічної території (УСЕТ), за В. Кубійовичем

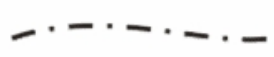

Масшттаб 1:2 250000

тнокультурно-геогр фічне положення ьвівської обл. 
ст новлять угорці $(12,1 \%)$ т румуни $(2,6 \%)$, ч стк росіян $-2,5 \%, \quad$ в ернівецькій обл. - румуни $(12,5 \%)$ т молдов ни $(7,3 \%)$, ч стк росіян $-4,1 \%$. йбільш кількість росіян з реєстров н у ьвівській т мельницькій обл стях $(3,6 \%)$, н йменш у ернопільській $(1,2 \%)$ т в но- $\mathrm{p}$ нківській $(1,8 \%)$ обл стях. стк польського н селення м є свої вл стивості. окрем , н йбільше поляків є у мельницькій $(1,6 \%)$ т ьвівській $(0,7 \%)$ обл стях, н йменш - в в но- $\mathrm{p}$ нківській т олинській (по 0,1\%).

одо ч стки білоруської меншини в регіоні, то вон незн чн, н йбільш у івненській обл. (1\%).

г лом у з хідному регіоні, окрім н зв них меншин, є й інші (їхня кількість н ближ ється до 100), середня ч стк у регіоні ст новить близько 0,8 \%.

днією 3 х р ктеристик етнон ціон льних вз ємин є ступінь етнон ціон льної моз їності, який відобр ж є скл дність етнон ціон льних поєдн нь різних держ в і регіонів. ля його розр хунку можн використовув ти різні пок зники, зокрем , індекс етнічної моз їчності . ккеля, який розр ховують з формулою [1, с. 53]:

$$
P_{j}=1-\sum_{i=1}^{k}(\pi)^{2}
$$

де $P_{j}$ - індекс етнічної моз їчності; $\pi$ - ч стк j-ї етнічної групи в н селенні регіону; $k$ - кількість етнічних груп.

ціон льний скл д н селення кр їни т обл стей її з хідного регіону, 2001 р.

\begin{tabular}{|c|c|c|c|c|c|c|c|c|}
\hline \multirow{2}{*}{ бл сть } & \multirow{2}{*}{$\begin{array}{c}\text { кр їнці, } \\
\%\end{array}$} & \multicolumn{6}{|c|}{ йбільші етнічні меншини, \% } & \multirow{2}{*}{ нші } \\
\hline & & росіяни & угорці & румуни & молдов ни & поляки & білоруси & \\
\hline олинськ & 96,9 & 2,4 & & & 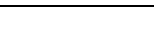 & 0,1 & 0,3 & 0,3 \\
\hline к рп тськ & 80,5 & 2,5 & 12,1 & 2,6 & _ & - & 0,1 & 2,2 \\
\hline $\begin{array}{l}\text { в но- } \\
\text { p нківськ }\end{array}$ & 97,5 & 1,8 & - & - & - & 0,1 & 0,1 & 0,5 \\
\hline ьвівськ & 94,8 & 3,6 & 0,02 & 0,01 & 0,03 & 0,7 & 0,2 & 0,6 \\
\hline івненськ & 95,9 & 2,6 & _ & _ & - & 0,2 & 1,0 & 0,3 \\
\hline ернопільськ & 97,8 & 1,2 & - & - & - & 0,3 & 0,1 & 0,6 \\
\hline мельницьк & 93,9 & 3,6 & - & - & 0,1 & 1,6 & 0,2 & 0,6 \\
\hline ернівецьк & 75,0 & 4,1 & _ & 12,5 & 7,3 & 0,4 & 0,2 & 0,5 \\
\hline $\begin{array}{l}\quad \text { г лом по } \\
\text { з хідному } \\
\text { регіоні } \\
\end{array}$ & 92,4 & 2,8 & 1,4 & 1,3 & 0,6 & 0,5 & $\mathbf{0 , 3}$ & $\mathbf{0 , 7}$ \\
\hline $\begin{array}{l}\text { г лом в } \\
\text { кр їні } \\
\end{array}$ & 77,8 & 17,3 & 0,3 & 0,3 & 0,5 & 0,3 & 0,6 & 2,9 \\
\hline
\end{tabular}

озр хов но $3[5,6]$.

ндекс етнічної моз їчності всього н селення кр їни ст новить 0,37 і є меншим, ніж у т ких сусідських держ в х, як лов ччин, олдов, умунія, ілорусь, т дещо вищим, ніж в горщині т ольщі. тже, у з хідному регіоні кр їни н йвищий рівень етнічної моз їчності в ернівецькій $(0,42)$ т к рп тській $(0,34)$ обл стях, де кількість укр їнського етнічного н селення н йменш і, відповідно, ч стк інших меншин н йбільш в регіоні. 
ешт обл стей регіону м є мінім льний пок зник етнічної моз їчності. прикл д, у мельницькій обл. рівень етнічної моз їчності ст новить 0,12 , у івненській - 0,08 , олинській - 0,06, в но- р нківській - 0,05, ернопільській - 0,04. ндекс етнічної моз їчності ьвівської обл. ст новить 0,10 , шо утричі менше від середнього пок зник по кр їні.

кими є з г льні риси етнокультурно-геогр фічного положення ьвівської обл. як моноетнічної території. тже, ьвівськ обл. розт шов н н периферії з хідного регіону кр їни. етнічними х р ктеристик ми близьк до н йбільш типових обл стей цього регіону. л стивості етнокультурно-геогр фічного положення відобр ж ють іiі геокультурно-моноетнічний х р ктер.

1. ністрянський . . тногеогр фія кр їни: вч. посібник. ьвів: 2008. $232 \mathrm{c}$.

2. оценко . ., інич . ., еликох тько . ., нцюр . . озселення в кр їні: проблеми т перспективи. :. кр їни кр їни, 2006. 269 с.

3. убійович ., уковський. рт кр їни. -б 1:2000 000. юнхен, риж, 1977/78. 38 с.

4. озинський. . тнічний скл дн селення ьвов . ьвів: ім. p нк, 2005. 355 с.

5. ціон льний скл д н селення ьвівської обл сті т його мовні озн ки 3 д ними сеукр їнського перепису н селення 2001 року. т тист. зб. ьвів: ,2003. 142 с.

6. ціон льний скл д н селення кр їни т його мовні озн ки 3 д ними сеукр їнського перепису н селення 2001 року / ред. . . с с уленк . . : ержкомст т, 2003. 249 с.

7. ерх ч . емогеогр фічне розт шув ння ьвівської обл сті // існ. ьвів. ун-ту. ер. геогр. 2000. ип. 27. . 212-217.

8. овенч $к \ldots$ тнокультурн геогр фія - одн із основних підсистем геогр фії культури // сторія укр. геогр фії. 2006. ип. 14. . 122-125.

9. удницький. личин т соборн кр їн // ому ми хочемо с мостійної кр їни. ьвів: віт, $1994 . \quad$. 350-411.

10. блій . . снови з г льної суспільної геогр фії. ідручник. ьвів: 2003. 444 с. 52 іл.

\section{ETHNOCULTURAL AND GEOGRAPHICAL LOCATION OF LVIV REGION}

\section{O. Davydenko}

Ivan Franko National University of Lviv, . Doroshenko St., 41, UA - 79000 Lviv, Ukraine

The conception of ethnocultural and geographical location is explained. The content of ethnocultural and geographical location of Lviv region is opened. The original map of ethnocultural and geographical location of Lviv region in the West area of Ukraine is worked out.

Key words: ethnocultural geography, geographical location, ethnocultural location, Lviv region. 


\section{- в ыденко \\ ввовский н цион льный университет имени вн н ул. . орошенко, 41, г. ьвов, 79000, кр ин}

боснов но понятие этнокультурно-геогр фического положения. скрыто сущность этнокультурно-геогр фического положения ьвовской обл. зр бот но оригин льную к рту этнокультурно-геогр фического положения ьвовской обл. в з п дном регионе кр ины.

лючевые слов : этнокультурн я геогр фия, геогр фическое положение, этнокультурно-геогр фическое положение, ьвовск я обл.

т ття н дійшл до редколегії 08.09.2009 рийнят до друку 20.12.2009 